\title{
EMPIRICAL EVALUATION OF THE EDUCATION EXPENDITURE IMPACT ON ECONOMIC GROWTH
}

\author{
Olena Vorhach
}

\begin{abstract}
This study expounds an empirical evaluation of (a) the interrelation between higher education expenditure and the share of highly qualified employed population of Ukraine, (b) the dependence of the population qualification level on the higher education expenditure in foreign countries and (c) dependence of these countries' GDP on the qualification of people. It has been hypothesized that an increase in funding for higher education contributes to the growth of the share of highly qualified population and the GDP volume per capita. The regression analysis results indicate inverse dependence of the population's qualification on real expenditure on higher education in Ukraine, that is, as the expenditure decreases, the share of population with high qualification increases, while the number of higher school teachers goes down. This situation is inconsistent with economic theory and is fraught with long-term adverse consequences for the national economy. The analysis of the average figures in 24 foreign countries has not revealed a pronounced dependence of the population qualification on expenditure on higher education and that of GDP on qualification. Nevertheless, the general trend is observed, i.e., in the countries with heavier expenditure on higher education there is a higher percentage of qualified population and higher GDP. The same trend, but in a more explicit form, has been established based on the results of regression analysis for the individual EU countries, confirming the research hypothesis.

Keywords: industry 4.0, economic growth, GDP, higher education expenditure, human capital, highly qualified staff, higher education
\end{abstract}

JEL Classification: H24, H52, 125, 015

Author:

Olena Vorhach

Institute of Industrial Economics of the National Academy of Sciences of Ukraine, 2 Maria Kapnist Street, Kyiv, Ukraine, 03057

E-mail: vorgach.lena@gmail.com

https://orcid.org/0000-0003-3686-4858

Citation: Vorhach, O. (2020). Empirical Evaluation of the Education Expenditure Impact on Economic Growth. Virtual Economics, 3(4), 48-71. https://doi.org/10.34021/ve.2020.03.04(3)

Received: June 3, 2020. Revised: August 12, 2020. Accepted: September 26, 2020.

(C) Author 2020. Licensed under the Creative Commons License - Attribution 4.0 International (CC BY 4.0)

Olena Vorhach

Virtual Economics, Vol. 3, No. 4, 2020 


\section{Introduction}

The level of people's education and skills is an important factor in economic growth, especially in the current environment. Digitalization and the Fourth Industrial Revolution determine significant changes in the nature of labor (Miśkiewicz, 2019; Dzwigol et al., 2020). This leads to a shift in occupations (some of them disappear, while the others emerge), increased requirements for the people's knowledge and skills (Frey \& Osborne, 2013; D2L, 2018), which will allow them to handle the high-tech equipment and manage the digital production processes (analyze big data, predict changes in the machine operation, make decisions in real time, etc.) (Benesovaa \& Tupa, 2017). The workforce with digital skills, so-called STEM (Science, Technology, Engineering, and Mathematics), is becoming an important component of modern industry (Industry 4.0), which requires the search for its development opportunities. In this regard, the importance of education, especially tertiary education, and its accessibility to a wider community of people for continuous professional development and retraining in line with the development of latest technologies is growing (D2L, 2018; Becker et al., 2011).

Yet there are reasonable fears (Stiglitz, 2014; Ford, 2016; Frey \& Osborne, 2013) that the development of Industry 4.0 could lead, on the one hand, to increased unemployment due to the automation and robotization of production processes and, on the other hand, to a shortage of qualified personnel due to changing training requirements and problems with the organization of rapid training and retraining. However, an analysis of a number of companies that have already implemented digital technology showed that at the current level of technological development, only about $5 \%$ of occupations are fully automated and about $1 / 3$ of individual tasks can be automated in $60 \%$ of occupations (McKinsey \& Company, 2017). It follows that, at least in the coming years, the employers do not plan to replace all employees with robots (albeit the relevance of production automation and robotization increasing significantly due to the pandemic COVID-19).

At the same time, there is still shortage of "digital" personnel, and by 2030, this shortage is expected to grow by $26 \%$ in the U.S. and by $22 \%$ in Europe in all industries (ManpowerGroup, 2019). Therefore, many managers of enterprises already implement in-company training and retraining courses, as well as outsource staff training through cooperation with educational institutions. Experience in some countries shows that investment in staff training pays off well; for example, in North America the cost of replacing employees accounts for more than $30 \%$ of the cost of wages, while the cost of training is less than $10 \%$ (ManpowerGroup, 2019).

An important role in overcoming the STEM staff shortage is played by the government, which is designated not only to finance education (primarily higher education, advanced training and retraining of adults), but also to create good conditions for the other economic actors to invest in human capital. The tasks of the government in this direction (Deloitte, 2018; IZA, 2018; Agolla, 2018) include reforming education to meet the requirements of digitalization and development of advanced technologies, its adequate direct and indirect budget financing (through provision of tax benefits and preferences to students). 
It is estimated that the accelerated industrial development and economic growth of a country is due not so much to digitalization in itself (Vyshnevskyi, 2020) but to human capital, i.e. the sum of knowledge, skills and abilities of people (Agolla, 2018). Therefore, the ability to develop Industry 4.0 and ensure economic growth largely depends on the organization of employees' continuous training in line with developing digital technologies, highlighting the need for investment in their education, professional development and retraining.

\section{Literature Review}

\subsection{Theoretical Literature}

The fundamentals of the modern concept of human capital were laid by the studies by the economists Schultz $(1960 ; 1961)$ and Becker $(1964 ; 1975)$. In particular, Schultz $(1960 ; 1961)$, who was one of the first to define human capital, considered investment in people's knowledge as that in production factors to obtain an additional product, that is, defined education as one of the main economic growth factors. In his papers, he emphasized investment as a required step to improve the quality of staff, and, in particular, he explored these investments beyond formal education.

G. Becker's $(1964,1975)$ paper findings guided many subsequent studies (Thurow, 1970; Romer, 1990; Nordhaug, 1993; Grossman, 1972; Lau et al., 1993; Nelson \& Phelps, 1966) in the field of human capital theory. He looked at investing in education both from the perspective of employees, allowing them to increase their income, from the perspective of a company, which increases its productivity and profits by training its personnel, as well as from the perspective of the state, which can enjoy economic growth due to educating people. Becker paid considerable attention to the analysis of investments in staff education and the impact of these investments on the companies' profits and economic benefits of the state.

In general, the theory of human capital has become widely spread in the scientific literature, and its followers continue to emphasize the importance of investment in staff education, justifying it by the growth of production and economy (Rosenzweig, 1990). However, it is not easy to identify and prove their direct relationship. Investments in education do not automatically provide economic growth; much depends on the circumstances of the place and time, state of the art and technology development, specific features of the national mentality and culture, including the technical one, quality of institutional environment, etc. In this regard, empirical studies (Mankiw et al., 1992; Benhabib et al., 1994; Judson, 1998; Benos \& Zotu, 2014; Jamel et al., 2020) are of great interest.

\subsection{Empirical Literature}

The analysis carried out by Pelinescu (2015) on the basis of the constructed model of human capital influence on economic growth has revealed close relations between (1) GDP per capita and innovation potential of employees, (2) GDP per capita and qualification, which corresponds to the conceptual provisions of the theory about positive influence of human 
capital quality on economic growth. At the same time, a negative correlation between GDP per capita and expenditure on education was revealed, which was explained by the different level of the countries' economic development. Negative results related to the indicators under study were observed during the global financial and economic crisis 2008-2009. In general, the author confirmed the positive impact of staff qualification on the economic growth in the country.

The results of the econometric model by Teixeira \& Queirosb (2016), based on selected indicators, showed that the interaction of human capital and high-tech industries has a positive impact on economic growth, but it follows different paths in countries with different development levels. In highly developed countries, this relationship is positive. In transition economies, human capital has a significant impact on overall economic growth, but the relation is negative in high-tech industries. According to the authors, in the absence of hightech production in a country, the availability of highly qualified personnel will not lead to faster economic growth.

The regression analysis of the relation between GDP and human capital indicators in the Scandinavian countries and southeast Europe conducted by Kokotovic (2016) showed that among the variables he selected, the relation between overall public expenditure on education and GDP is the closest. Besides, the author notes that the human capital has the greatest impact on GDP growth in developed countries.

The study by Radulescu et al. (2018) emphasizes the role of higher education in ensuring the economic development of several EU countries (Poland, Czech Republic, Slovakia, Hungary, Bulgaria, and Romania). The results of the regression analysis of the tertiary education impact on the economic competitiveness and GDP per capita showed a strong correlation of the higher education variable with other variables. This allowed the authors to argue that higher education improves the country's economic competitiveness and contributes to GDP growth.

From a brief review of scientific papers, it follows that theoretical and empirical works of economists generally confirm the positive impact of the level of people's education on economic growth, taking into account the other factors (including the overall level of the country's development). Further, in empirical studies, scientists note the difficulties in interpreting the results of analysis for transition economies (with a low level of technological development) and during economic crises (Pelinescu, 2015; Teixeira \& Queirosb, 2016; Kokotovic, 2016; Radulescu et al., 2018). They also draw attention to the fact that the interaction of highly qualified personnel and new production technologies can help accelerate economic growth.

The issues of assessing the impact of education financing on economic growth are also relevant for Ukraine, which aims at digitalizing its economy. According to recent research, the country has certain prospects for developing the national smart industry in certain sectors, but so far there have been many risks that may prevent this from occurring, including in the domestic labor market (Vyshnevskyi et al., 2019; Vishnevsky \& Knjazev, 2017). Priority is given 
to the further development of human capital capable of working with new technologies, based on developing and implementing strategies for the effective use, preservation and development of labor potential (including the research and production) in the course of implementing Industry 4.0 technologies, as well as staff retraining following STEM principles (Pankova et al., 2020).

In turn, it is necessary to also note the works by the scientists (Bogachov et al., 2020; Boiko et al., 2019; Czyżewski et al., 2019; Chygryn et al. 2020; Dalevska et al., 2019; Dementyev \& Kwilinski, 2020; Drozdz et al., 2019; 2020; Dzwigol, 2019a; 2019b; 2020a; 2020b; 2020c; Dzwigol \& Wolniak, 2018; Dzwigol \& Dźwigoł-Barosz, 2018; 2020; Dzwigol et al., 2019a; 2019b; 2019c; 2020a; Furmaniak et al., 2018; 2019a; 2019b; Kharazishvili et al., 2020; Kondratenko et al., 2020; Kuzior et al., 2020; Kwilinski, 2017; 2018a; 2018b; 2018c; 2018d; 2019; Kwilinski et al., 2019a; 2019b; 2019c; 2019d; 2019e; 2019f; 2019g; 2020a; 2020b; 2020c; 2020d; Kwilinski \& Kuzior, 2020; Lakhno et al., 2018; Miskiewicz, 2017a; 2017b; 2018; 2020a; 2020b; Miśkiewicz \& Wolniak, 2020; Pająk et al., 2016; 2017; Prokopenko \& Miśkiewicz, 2020; Saługa et al., 2020; Savchenko et al., 2019; Tkachenko et al., 2019a; 2019b; 2019c; 2019d; 2019e; Yelnikova \& Miskiewicz, 2020), in which special attention is paid to the issues of processes' informatization in the context of increasing the efficiency of the economic mechanisms' functioning of various scales of activity.

Since the development of digital economy and the establishment of Industry 4.0 increases the need for highly qualified personnel in Ukraine, it directs the focus of economists on education as an important factor in forming human capital and economic development. In this regard, this article is intended to test the hypothesis that an increase in expenditure on tertiary education increases the share of the population with high qualifications in the country, and this, in turn, contributes to its economic growth.

Based on the above, the purpose of this article is to empirically evaluate the dependence of the population's professional development on the amount of higher education expenditure in Ukraine and some foreign countries and to justify the impact of higher education on economic growth.

\section{Methodology}

The research was conducted using the comparative and regression analysis based on two data sets, for Ukraine and foreign countries.

The data for Ukraine include:

1) Employment indicators: the total number of employed population 15-70 years old and in terms of qualification levels (with high and low qualification). The highly qualified people are the sum of employed population 15-70 years old with full higher and basic higher education ISCED2011 levels 5 to 8; the low qualified ones are the sum of employed population of the same age with incomplete higher, vocational, full general and basic general secondary 
education, as well as with primary or no education at all (State Statistics Service of Ukraine, 2020).

2) Tertiary education financing indicators: in terms of the sources of financing (governmental and non-governmental) and stages of higher education (first and second stages of higher education), which correspond to ISCED2011 levels 5 to 8, as well as the total costs, represented by the sum of first and second stages. Expenditure of the public sector on tertiary education is covered from the state and local budgets, while the expenditure of the nongovernmental sector - from private enterprises and households. The first stage of higher education includes obtaining an appropriate degree in higher education institutions of the $1^{\text {st }}$ to $4^{\text {th }}$ accreditation degrees, while the second (postgraduate higher education) covers postgraduate and doctoral studies, postgraduate education in institutions of the $3^{\text {rd }}$ to $4^{\text {th }}$ accreditation levels, in particular in academies, institutes, centers for advanced training, retraining, etc. (State Statistics Service of Ukraine, 2020).

The following indicators were used to generate a data set for foreign countries:

1) GDP per capita;

2) a total (governmental and non-governmental) expenditure on higher education ISCED2011 levels 5 to 8 per student;

3) a share of population with higher education of ISCED2011 levels 5 to 815 -64 years old.

The data of Ukraine are received on the website of the State Statistics Service of Ukraine from the statistical collection of Economic Activity of the Population of Ukraine, Labor Market Section, on employment indicators, and collection of National Accounts of Education of Ukraine, Education section, on financing indicators. The data of foreign countries were collected on the OECD website, Productivity Section, on GDP per capita and Education and Training Section on the total expenditure on higher education of ISCED2011 levels 5 to 8 per 1 student (OECD, 2020a; OECD, 2020b), as well as on the Eurostat website, Population by Educational Attainment Level Section on the share of population with higher education of ISCED2011 levels 5 to 8 at the age of 15-64 years old (Eurostat, 2020). The research period for Ukraine and foreign countries covers the years for which the data on all selected indicators are available.

\section{Results and Discussion}

\subsection{Empirical Results for Ukraine}

As the analysis of the scientific literature has shown, education is an important component of the country's economic growth. Providing people with education, particularly higher education, requires significant financial investments from the state and individuals, especially to train STEM personnel. Consequently, the higher the country's current expenditure for education (advanced training and retraining) of the population is, the more opportunities it has, with all other things being equal, to quickly address the problem of deficit of the highly qualified personnel required for the modern industry development. 
Since this issue is also relevant for Ukraine, it is advisable to analyze and evaluate the capabilities of the state in terms of training the highly qualified personnel. For this purpose, it is required to investigate changes in the higher education expenditure in the long term, as well as changes in the share of the population with high qualification in the country, and to determine whether the level of qualification depends on the education increased expenditure.

Table 1 presents the data on the number of highly qualified, low skilled and total employed population of Ukraine for 2007-2018. Since some years of this period take into account the data on the temporarily occupied territories of Crimea, Donetsk and Luhansk regions, before entering the table, they were given in a comparable form by calculating the factor of transition to a new reporting pattern based on the total number of employees.

According to Table 1, the period under study shows a decrease in the number of employed people, the sharpest after 2014. In terms of qualification levels, the decline was observed mainly as regards low-skilled population, while a slight decrease in their number began after the financial and economic slowdown of 2008-2009, which may be explained by labor migration to foreign countries. At the same time, a slow growth of highly qualified population was observed throughout the entire period.

Table 1. Employment Indicators in Ukraine by Skill Level, thousands of people

\begin{tabular}{cccc}
\hline Year & Highly qualified & Low qualified & Total employees \\
\hline 2007 & 4,890 & 14,895 & 19,785 \\
\hline 2008 & 4,956 & 14,893 & 19,849 \\
\hline 2009 & 5,034 & 14,076 & 19,110 \\
\hline 2010 & 5,211 & 13,969 & 19,180 \\
\hline 2011 & 5,391 & 13,844 & 19,235 \\
\hline 2012 & 5,568 & 13,694 & 19,261 \\
\hline 2013 & 5,583 & 13,731 & 19,314 \\
\hline 2014 & 5,854 & 12,219 & 18,073 \\
\hline 2015 & 5,464 & 10,980 & 16,443 \\
\hline 2016 & 5,439 & 10,838 & 16,277 \\
\hline 2017 & 5,504 & 10,652 & 16,156 \\
\hline 2018 & 5,734 & 10,627 & 16,361 \\
\hline
\end{tabular}

Source: developed by the author based on the data of (State Statistics Service of Ukraine, 2020).

To evaluate the impact of higher education expenditure on the increase in the number of highly qualified population in the country, the analysis of the overall financing of higher education was carried out in terms of funding sources and stages of education in the period under study. Before entering the data into Table 2, they were converted into a comparable form by linking them to the prices of 2010. Further, the data in Table 2 were translated into 
million U.S. dollars at the exchange rate of 2010 and excluding the temporarily occupied territories.

When comparing the data in Table 2, it was found that in 2011, the total expenditure on higher education in Ukraine began to gradually decline, but the largest decrease was observed after 2014. The situation is similar if we consider the costs in terms of the sources of funding and stages of higher education. At the same time, the amount of costs for the second stage of higher education (postgraduate and doctoral studies, advanced training and retraining) is much lower than for the first stage. That is, adult education and retraining is financed to a lesser extent, which is inconsistent with trends in many countries across the world, considering this as an opportunity to quickly address the STEM personnel shortage. The share of governmental expenditure on education in Ukraine is significantly higher than that of nongovernmental expenditure, despite the fact that the government has significantly reduced these costs over the past five years. Non-government expenditure has also decreased in real terms.

Table 2. Expenditure of Ukraine on Higher Education in 2007-2018

\begin{tabular}{cccccc}
\hline Year & $\begin{array}{c}\text { Total } \\
\text { expenditure } \\
\text { on higher } \\
\text { education } \\
\text { ISCED2011 } \\
\text { levels 5 to 8 }\end{array}$ & $\begin{array}{c}\text { Governmental } \\
\text { expenditure on } \\
\text { higher education } \\
\text { ISCED2011 levels } \\
\text { 5 to 8 }\end{array}$ & $\begin{array}{c}\text { Non-governmental } \\
\text { expenditure on } \\
\text { higher education } \\
\text { ISCED2011 levels } \\
5 \text { to 8 }\end{array}$ & $\begin{array}{c}\text { Total } \\
\text { expenditure } \\
\text { on } \\
\text { Stage I of } \\
\text { higher } \\
\text { education }\end{array}$ & $\begin{array}{c}\text { Total } \\
\text { expenditure } \\
\text { on Stage Il of } \\
\text { higher } \\
\text { education }\end{array}$ \\
\hline 2007 & 4,643 & 2,685 & 1,958 & 4,464 & 180 \\
\hline 2008 & 4,717 & 2,997 & 1,720 & 4,534 & 182 \\
\hline 2009 & 4,646 & 2,994 & 1,653 & 4,482 & 165 \\
\hline 2010 & 4,753 & 3,142 & 1,611 & 4,571 & 181 \\
\hline 2011 & 4,393 & 2,930 & 1,463 & 4,226 & 167 \\
\hline 2012 & 4,322 & 3,004 & 1,318 & 4,162 & 160 \\
\hline 2013 & 4,264 & 2,945 & 1,319 & 4,074 & 190 \\
\hline 2014 & 3,557 & 2,488 & 1,069 & 3,408 & 149 \\
\hline 2015 & 2,973 & 1,951 & 1,022 & 2,296 & 91 \\
\hline 2016 & 2,725 & 1,895 & 830 & 2,607 & 118 \\
\hline 2017 & 2,431 & 1,721 & 710 & 2,314 & 117 \\
\hline 2018 & 2,393 & 1,697 & 697 & 2,266 & 127 \\
\hline
\end{tabular}

Source: developed by the author based on the data of (State Statistics Service of Ukraine, 2020).

Then the dependence of qualification growth on the increase in higher education expenditure in Ukraine for 2007-2018 was analyzed (Table 3). For this purpose, based on the values of Table 1, the share of highly qualified population in the total number of the employed annually was calculated and compared with higher education expenditures from Table 2. 
The amount of the total higher education expenditure in this period is gradually decreasing against the background of slow growth of the share of highly qualified population (Table 3), i.e. qualification is growing regardless of the amount of expenditure on it. The graphical presentation of data (Fig. 1) shows the inverse dependence of qualification on education expenses more clearly (with the correlation factor being 0.95), i.e. the share of highly qualified personnel increases with decreasing higher education expenditure.

Table 3. Comparison of a Share of Highly Qualified Population and Higher Education Expenditure

\begin{tabular}{ccc}
\hline Year & $\begin{array}{c}\text { Share of highly qualified population, \% } \\
\text { of total employees }\end{array}$ & $\begin{array}{c}\text { Total expenditure on higher education } \\
\text { ISCED2011 levels 5 to 8, US\$ million }\end{array}$ \\
\hline 2007 & 24.7 & 4,643 \\
\hline 2008 & 25.0 & 4,717 \\
\hline 2009 & 26.3 & 4,646 \\
\hline 2010 & 27.2 & 4,753 \\
\hline 2011 & 28.0 & 4,393 \\
\hline 2012 & 28.9 & 4,322 \\
\hline 2013 & 28.9 & 4,264 \\
\hline 2014 & 32.4 & 3,557 \\
\hline 2015 & 33.2 & 2,973 \\
\hline 2016 & 33.4 & 2,725 \\
\hline 2017 & 34.1 & 2,431 \\
\hline 2018 & 35.0 & 2,393 \\
\hline
\end{tabular}

Source: developed by the author based on the data of (State Statistics Service of Ukraine, 2020).

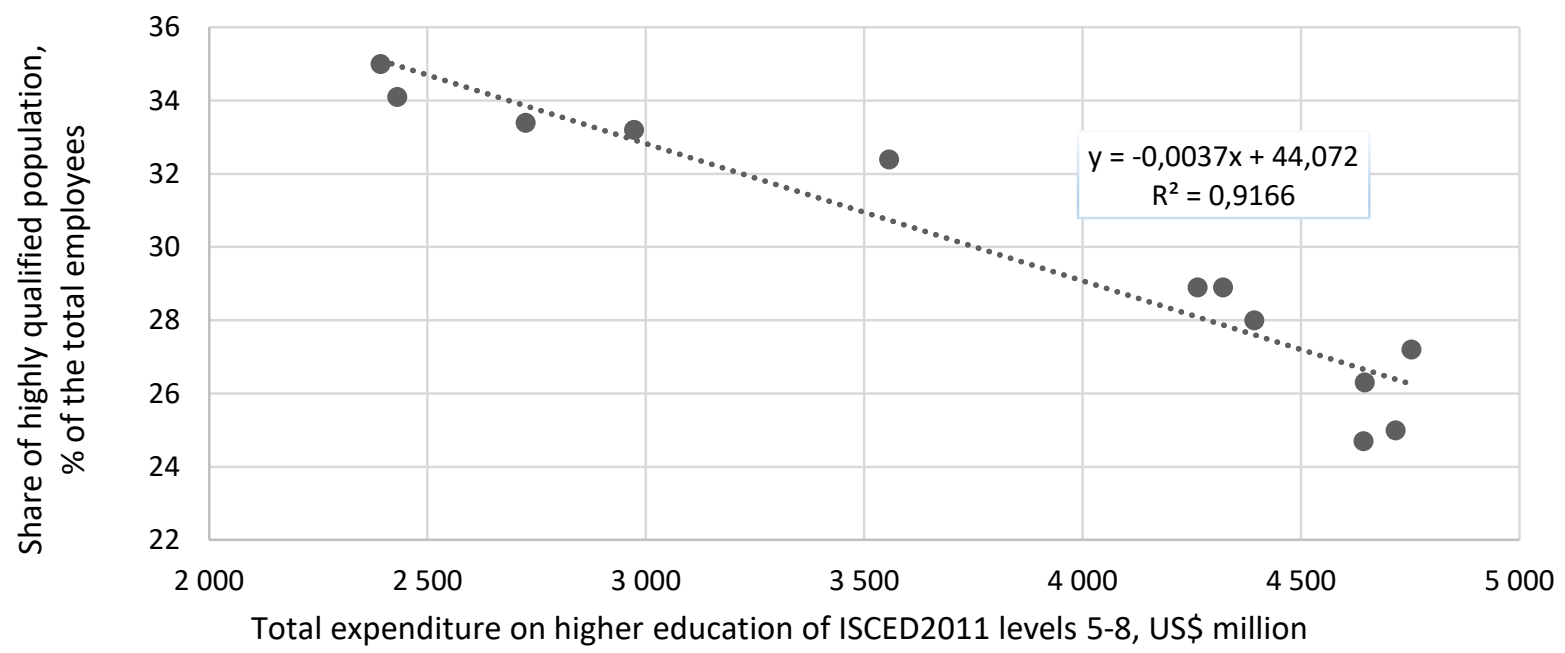

Figure 1. Statistical Correlation between the Share of Highly Qualified Population versus the Total Mass of Employees and Higher Education Expenditure in 2007-2018 in Ukraine. Source: developed by the author. 
Such a result clearly contradicts the provisions of economic theory and allows assuming either distortions in statistical estimates of the real level of the personnel qualification, and/or the presence in Ukraine of a significant "shadow" pay for teachers, and/or the operation of the educational sphere, in this case, the employees in the system of higher, post-secondary professional education and scientific sphere, at the expense of reduced pay for the teachers while maintaining their workload. As a rule, this is observed when the number of budget recipients (educational institutions) is reduced, as well as when budget funding for their maintenance and organization of the educational process therein is reduced.

The decrease in public expenditure on higher education in Ukraine is a result of the reform ongoing since 2014, at the beginning of which, along with improved quality of education and knowledge gained, it has been planned to eliminate some higher education institutions (Osvita, 2015). According to the State Statistics Service of Ukraine, the number of higher education institutions within one academic year since the beginning of the reform has decreased significantly, i.e. the number of institutions of the $3^{\text {rd }}$ to $4^{\text {th }}$ accreditation levels in $2013 / 14$ academic year was 309 , while that in $2014 / 15-277$, and the number of institutions of the $1^{\text {st }}$ to $2^{\text {nd }}$ accounted for 458 and 387 , respectively. This was accompanied by a reduction in the number of full-time staff and an increase in part-time employment. The number of students also decreased, which is explained by the fall of the birth rate in 1998-2003 (the years of their admission to higher education institutions are 2015-2020). Therefore, the burden on institutions and teachers of higher education remains the same (due to the reduction of both teachers and students), and may increase in the future due to an increase in the birth rate since 2004.

During the reform, the Law on Education (Verkhovna Rada of Ukraine, 2017) fixed the guaranteed minimum wage for teachers of higher education institutions, increased the requirements for accreditation of institutions and certification of teachers. This has not yet had a significant impact on education quality, but did lead to lower real budget expenditure for it and reduced the number of institutions and teachers. Recent legislative changes (The Cabinet of Ministers of Ukraine, 2019) have radically changed the way the institutions of higher education are funded, i.e. not by the number of students, but by their educational, scientific and international activities, which has helped to reduce governmental funding of many of them. Besides, the Cabinet of Ministers of Ukraine (The Cabinet of Ministers of Ukraine, 2020) introduced a step-wise increase in the cost of contract training for popular specialties up to $80 \%$ of the cost of budget expenditure on them, which may have a negative impact on people's incentives to study and lead to a decrease in private funding of higher education.

Thus, reduction of higher education budget expenditure is a consequence of the reform carried out by the government, which suggests a further reduction in funding. At the same time, the burden on employees in the higher education sector remains high. During the past years, non-governmental expenditure on education have been decreasing, albeit insignificantly, but steadily. In the future, such actions may lead to a decrease in the stratum of population with higher education in Ukraine (taking into account its quality), which will 
hinder availability of highly qualified personnel, because the situation when costs are reduced and results grow cannot last for long. Contrarily, in foreign countries, the government expenditure on higher education is increasing (as described below).

\subsection{Empirical Results for European Countries}

By investing in the knowledge and professional skills of people, the state directly or indirectly invests in production, because more highly skilled labor is involved in creating a national product, which, in turn, contributes to economic growth. In this context, it is advisable to study the trends observed in foreign countries.

Developing the ideas of research (Pelinescu, 2015; Kokotovic, 2016; Radulescu et al., 2018), the relation among the volume of GDP per capita, expenditure on higher education and the share of highly qualified personnel in the selected European countries (the graph shows the size of GDP) were analyzed based on the average data for 2014-2016 (Fig. 2).

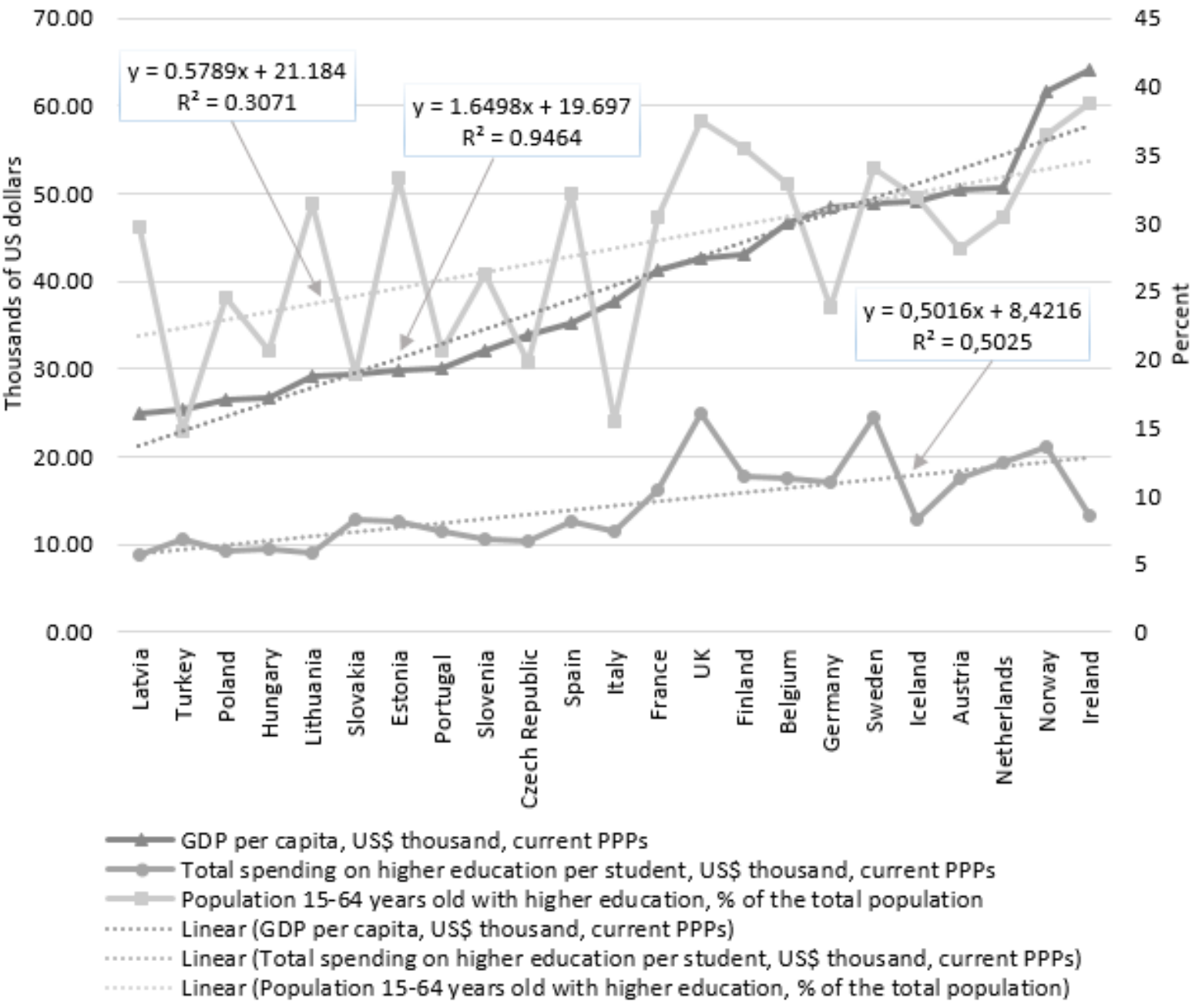

Figure 2. Statistical Correlation of GDP per Capita, Amount of Higher Education Expenditure and Share of Population with Higher Education.

Source: developed by the author according to the data of (OECD, 2020a; OECD, 2020b; Eurostat, 2020). 
Visual evaluation of the graph (Fig. 2) shows a general trend that the countries with higher GDP per capita have higher expenditure on education and more skilled population. That is, in general, there is a direct and logical dependence, i.e. an increase in expenditure on education $\Rightarrow$ increased qualification of the people $\Rightarrow$ economic growth. At the same time, it should be noted that linear dependence describes the growth of GDP per capita in the selected countries well (the determination factor being 0.9464), while the expenditure on education (0.5025) and the share of highly qualified personnel $(0.3071)$ is worse.

It should be taken into account that such results are partly explained by specific problems with higher education financing in individual countries (e.g. Lithuania and Latvia), as well as by the fact that in the countries with a less developed industrial sector there is no acute need for highly qualified personnel. In general, as was mentioned above, the cost-qualificationeconomic growth dependencies can be traced (Fig. 2), which provides a basis for their research at the level of individual countries.

\subsection{Empirical Results for Selected European Countries}

Taking into account Ukraine's European integration aspirations, it is advisable to analyze the interdependence of higher education expenditure, the share of highly qualified population, and GDP in individual EU countries. For this purpose, new EU member states (Poland, Estonia, Czech Republic, Slovakia, Latvia, Lithuania, and Slovenia), which, like Ukraine, used to be classified as plan-based economies, were included in the study.

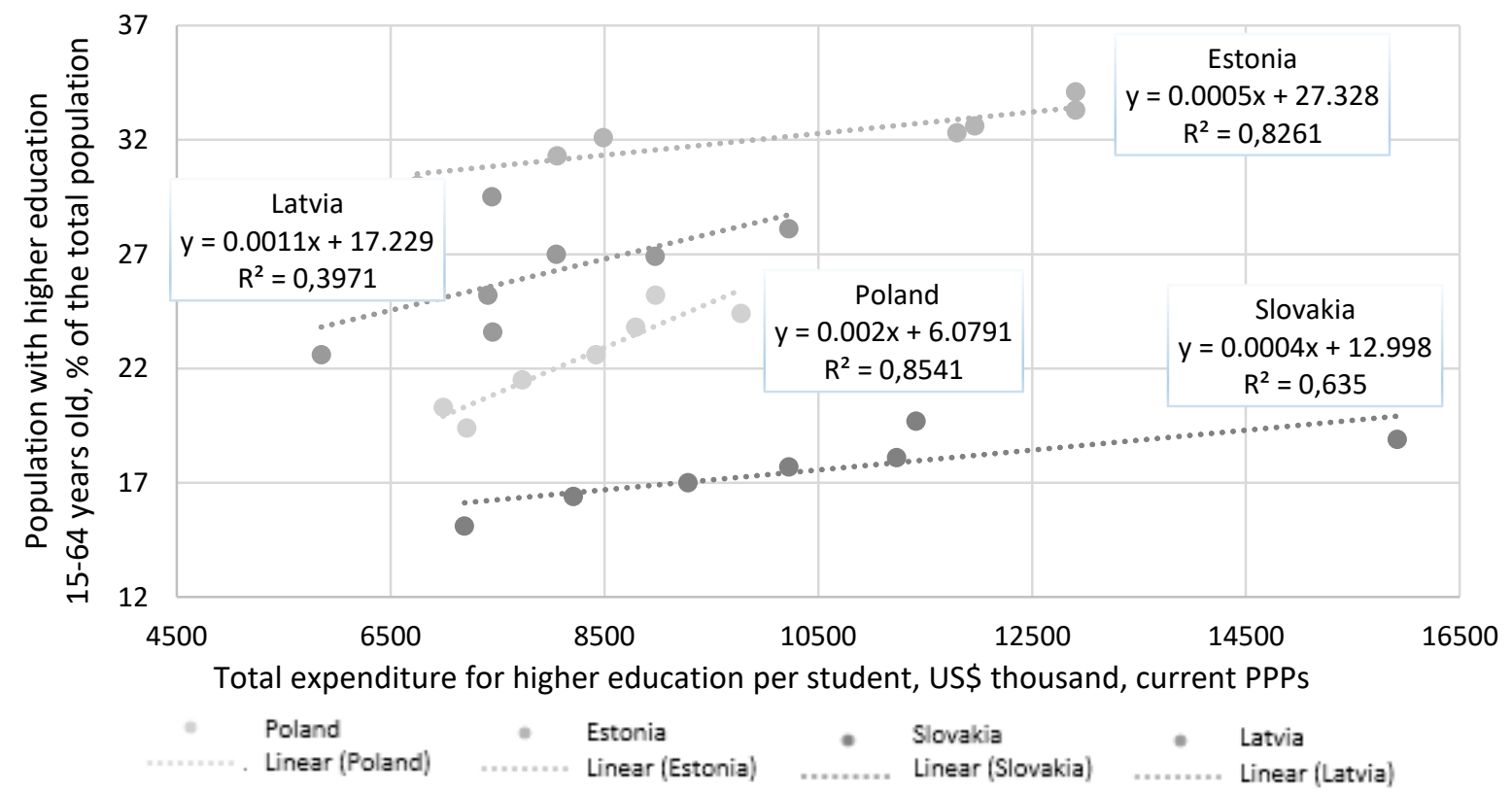

Figure 3. Statistical Correlation between the Share of Highly Qualified Population and the Amount of Higher Education Expenditure in Poland, Estonia, Slovakia, and Latvia.

Source: developed by the author based on the data of (OECD, 2020a; Eurostat, 2020). 


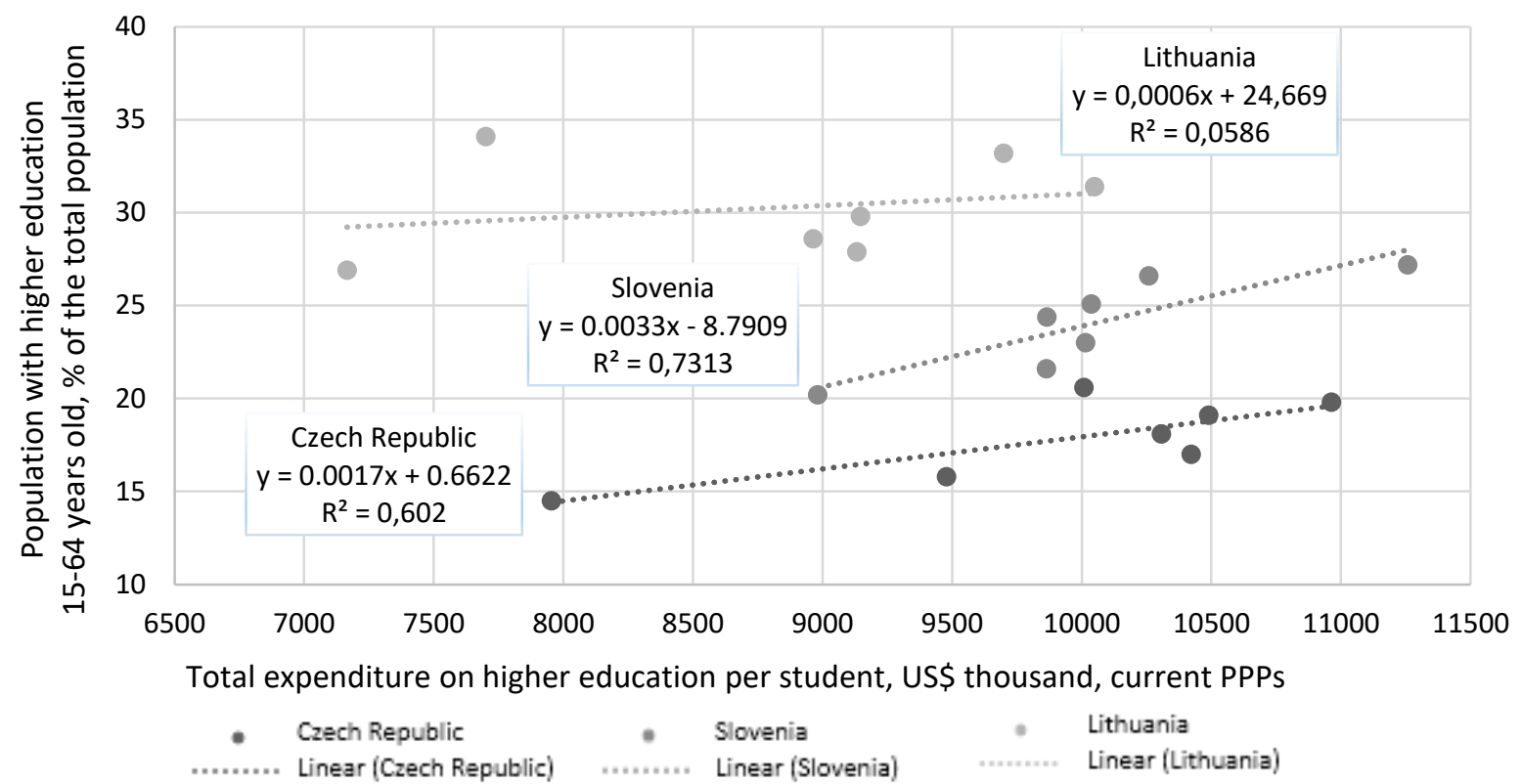

Figure 4. Statistical Relation between the Share of Highly Qualified Population and the Amount of Higher Education Expenditure in the Czech Republic, Slovenia, and Lithuania.

Source: developed by the author using the data of (OECD, 2020a; Eurostat, 2020).

Based on the statistical data (OECD, 2020a; OECD, 2020b) on total (governmental and nongovernmental) higher education expenditure per student and GDP per capita, as well as the data of (Eurostat, 2020) on the share of population with higher education, Fig. 3 and Fig. 4 show a graph of statistical dependence of selected indicators per each country in 2010-2016.

The diagrams of approximating functions by foreign countries (Fig. 3, Fig. 4) reflect the presence of linear dependence of the share of highly qualified personnel on higher education expenditure:

1) the determination factors of Poland (0.8541), Estonia (0.8261), and Slovenia (0.7313) have high values, indicating a strong correlation between the indicators;

2 ) the Czech Republic (0.602) and Slovakia (0.635) are characterized by the presence of an average correlation and Latvia $(0.3971)$ - by a weak correlation;

3) Lithuania shows almost no dependence of qualification on expenditure (the determination factor being 0.0586).

According to the data of (OECD, 2020a), the Czech Republic has seen a slight decrease in expenditure in 2013 and 2016 against the background of an overall increase; Slovakia and Latvia have seen a sharp decline in 2016, while Lithuania's expenditure is leapfrogging throughout the period.

In Latvia, this is due to the reduction in the number of students (by $17 \%$ over the period under study) (OECD, 2019a) and the reform of higher education, which resulted in introducing a new model for its financing in 2015-2016 aimed at improving the quality of education and a model for teachers' remuneration aimed at improving the quality of their work and the efficient use 
of public funds (OECD, 2017a). Fluctuations in higher education expenditure in Lithuania were influenced by the demographic situation, which led to a $32 \%$ decrease in the number of students (over the years under study), resulting in a decrease in the number of teachers and higher education institutions. Further, low public funding for higher education in Lithuania is $1.1 \%$ of the country's GDP (OECD, 2019b; OECD, 2017b).

Contemporary studies (UNESCO, 2016; Hanushek et al., 2008) point to the fact that it is highly qualified staff that has a strong influence on GDP growth during the periods of economic growth. Therefore, given the rapid development of Industry 4.0, the role of highly skilled labor is increasing, as it promotes the launch of new technologies into production.

Fig. 5 and Fig. 6 present statistical dependence of GDP per capita on high qualification of employees for 2010-2016 in the foreign countries under study.

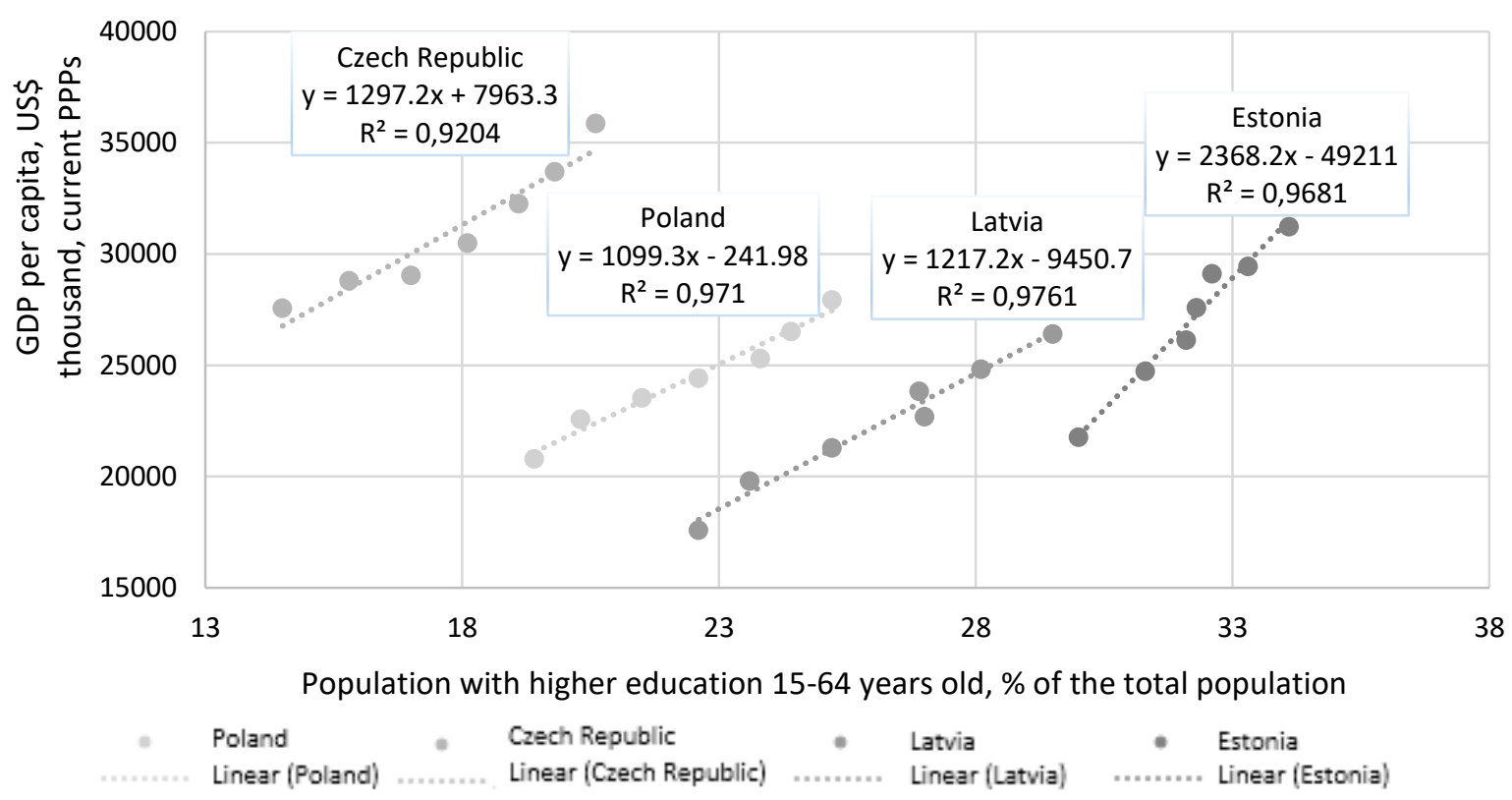

Figure 5. Statistical Relation of GDP Per Capita and the Share of Highly Qualified Population in Poland, Czech Republic, Latvia, and Estonia.

Source: developed by the author using the data of (OECD, 2020b; Eurostat, 2020).

All considered countries show a strict linear dependence between GDP growth and increase in the share of population with higher education (Fig. 5, Fig. 6). This is proved by high values of determination factors: Poland - 0.971, Estonia - 0.9681, Czech Republic - 0.9204, Slovakia -0.9404 , Latvia -0.9761 , Lithuania -0.9267 , and Slovenia -0.8861 . This allows asserting that high qualification of the population is positively related to the volume of the country's GDP and, therefore, improved skills of people contribute to economic growth. 


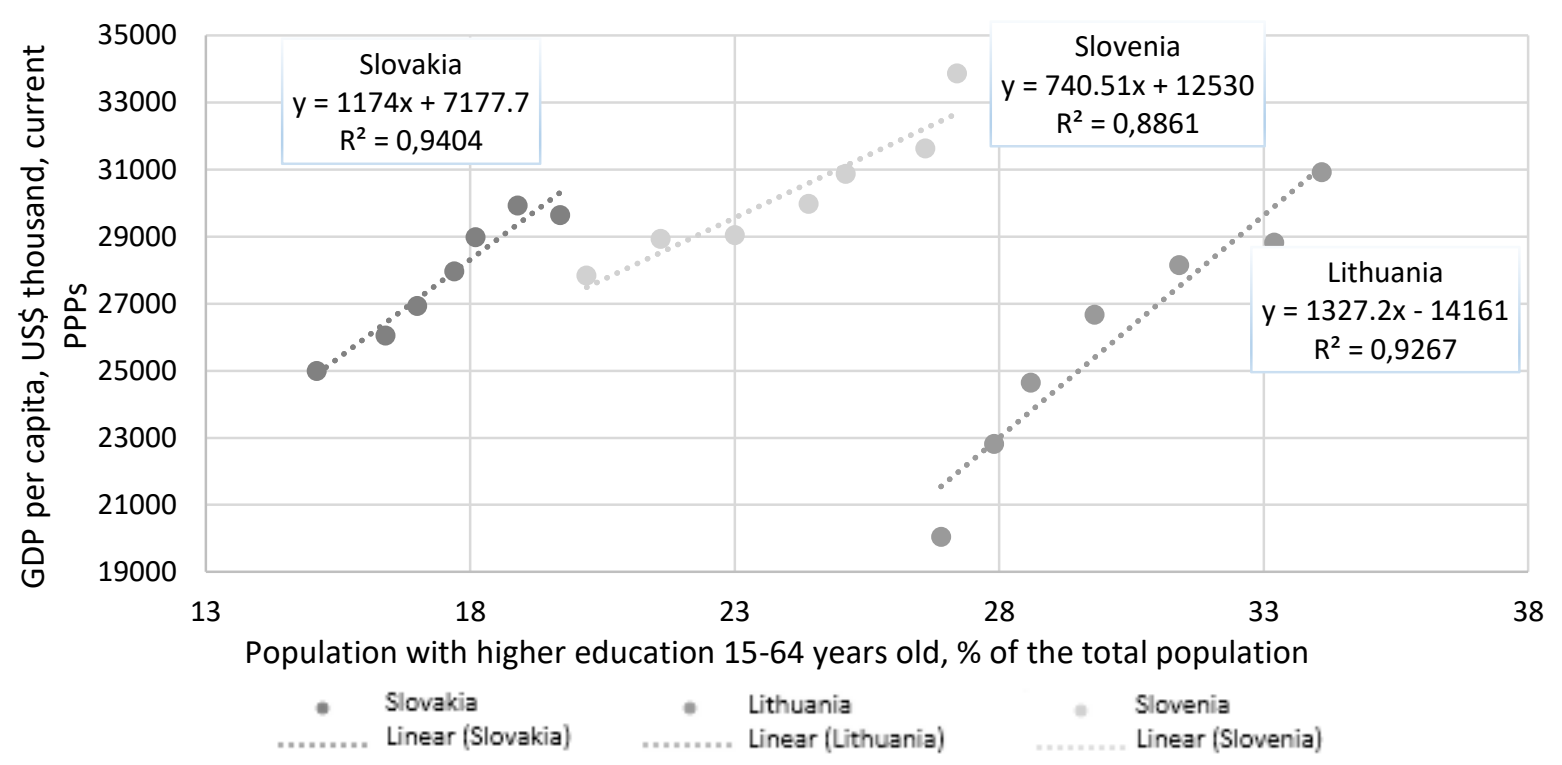

Figure 6. Statistical Relation between GDP per Capita and a Share of Highly Skilled Population in Slovakia, Lithuania, and Slovenia.

Source: developed by the author using the data of (OECD, 2020b; Eurostat, 2020).

In general, the analysis of the new EU member states allowed identifying: (a) the existence of a dependency of the highly skilled population on higher education expenditure and (b) the existence of a dependency of GDP on the share of highly skilled population. However, for the sake of the picture completeness, it is advisable to perform calculations and evaluate the existence of such a dependence in the other EU countries, which may constitute the subject of further research in this direction.

\section{Conclusions}

Following the economic theory, it can be argued that investment in education has a positive impact on the skills level of the population, which, in turn, leads to higher productivity and, all other things being equal, contributes to sustainable economic growth. In practice, taking into account the level of science and technology, as well as the nature of the institutional environment, not all countries, including Ukraine, are able to achieve this.

The analysis conducted in the article showed that during the period under study, the share of highly qualified population of Ukraine is growing gradually. This could be considered as a good basis for forming STEM-personnel and increasing the national labor productivity, if the real costs of higher education, professional development and retraining of people (almost twice in 2015-2018), mainly the governmental ones, were not reduced. This is partly due to the reform of the education system, which, according to the government's plan, should improve its quality. It is difficult to evaluate its results so far, but currently there is a decrease in higher education funding, as well as a decrease in the number of universities and teachers. 
The regression analysis revealed an inverse dependence of people's qualification on real expenditure on higher education in Ukraine. That is, a decrease in funding is accompanied by a certain increase in the share of people with high qualifications, which is inconsistent with the theory of human capital and practice in many European countries. Obviously, this situation cannot last long and may lead to long-term adverse consequences for the national economy.

The analysis of relevant indicators of EU member states has shown that, in general, there is no strongly pronounced dependence of the population's qualifications on education expenditure and GDP on qualifications. However, it can be argued that there is a certain general trend according to which the countries with high expenditure on higher education have a higher percentage of highly skilled population and higher GDP. Regression analyses of individual EU countries that are former plan-based economies have confirmed these findings. Most of them show a strong linear relationship between people's qualifications and expenditure on higher education. Also, there is an even stronger linear dependence of GDP on the qualifications of people in these countries.

Thus, in Europe the hypothesis that those countries, which better finance higher education (re-training and professional development) of people, provide an increase in the share of highly qualified work and, consequently (given the achieved level of science and technology), ensure the GDP growth per capita is confirmed analytically.

To sum up, it should be noted that the revealed inverse dependence of the share of highly qualified population in Ukraine on real expenditure on higher education cannot be considered normal, especially against the background of the Fourth Industrial Revolution. Reduction of higher education expenditure in Ukraine backed up by an insignificant increase in the number of highly qualified population (taking into account the problems of education quality) reduces the opportunities of the country in terms of STEM-personnel formation and economic growth. To avoid irreversible changes in the quality of human capital, it is advisable for the government to reconsider the attitude towards governmental funding of higher education and to stimulate private funding, bringing it in line with the best European practices.

In order to determine specific ways to solve these problems, the further scientific research is needed to obtain quantitative estimates of the expected return on investment in human capital, taking into account the institutional specific features of Ukraine.

\section{References}

Agolla, J. E. (2018). Human Capital in the Smart Manufacturing and Industry 4.0 Revolution. Digital Transformation in Smart Manufacturing, pp. 41-58. http://doi.org/10.5772/intechopen.73575

Becker, G. (1964). Human Capital: A Theoretical and Empirical Analysis, with Special Reference to Education. New York: National Bureau of Economic Research. 
Becker, G. (1975). Investment in Human Capital: Effects on Earnings. Retrieved from http://www.nber.org/chapters/c3733.pdf

Becker, S. O., Hornung, E., \& Woessmann, L. (2011). Education and Catch-Up in the Industrial Revolution. American Economic Journal: Macroeconomics, 3, 92-126.

Benesovaa, A., \& Tupa, J. (2017). Requirements for Education and Qualification of People in Industry 4.0. Procedia Manufacturing, 11, 2195-2202.

Benhabib, J., \& Spiegel, M. (1994). The Role of Human Capital in Economic Development: Evidence from Aggregate Cross-Country Data. Journal of Monetary Economics, 34, 143-179. https://doi.org/10.1016/0304-3932(94)90047-7

Benos, N., \& Zotu, S. (2014). Education and Economic Growth: A Meta-Regression Analysis. World Development, 64, 669-689. https://doi.org/10.1016/j.worlddev.2014.06.034

Boiko, V., Kwilinski, A., Misiuk, M., \& Boiko, L. (2019). Competitive Advantages of Wholesale Markets of Agricultural Products as a Type of Entrepreneurial Activity: The Experience of Ukraine and Poland. Economic Annals-XXI, 175(1-2), 68-72. https://doi.org/10.21003/ea.V175-12

Czyżewski, B., Matuszczak, A., \& Miskiewicz, R. (2019). Public Goods Versus the Farm Price-Cost Squeeze: Shaping the Sustainability of the EU's Common Agricultural Policy. Technological and Economic Development of Economy, 25(1), 82-102. https://doi.org/10.3846/tede.2019.7449

Chygryn, O., Bilan, Y., \& Kwilinski, A. (2020). Stakeholders of Green Competitiveness: Innovative Approaches for Creating Communicative System. Marketing and Management of Innovations, 3, 356-368. https://doi.org/10.21272/mmi.2020.3-26

Dalevska, N., Khobta, V., Kwilinski, A., \& Kravchenko, S. (2019). A Model for Estimating Social and Economic Indicators of Sustainable Development. Entrepreneurship and Sustainability Issues, 6(4), 1839-1860. https://doi.org/10.9770/jesi.2019.6.4(21)

Dementyev, V.V., \& Kwilinski, A. (2020). Institutsionalnaya sostavlyayuschaya izderzhek proizvodstva [Institutional Component of Production Costs]. Journal of Institutional Studies, 12(1), 100-116. https://doi.org/10.17835/2076-6297.2020.12.1.100-116

Deloitte (2018). Preparing Tomorrow's Workforce for the Fourth Industrial Revolution. For business: A Framework for Action. Deloitte. Retrieved from https://www2.deloitte.com/content/dam/Deloitte/global/Documents/About-Deloitte/gxpreparing-tomorrow-workforce-for-4IR.pdf

D2L (2018). The Future of Work and Learning in the Age of the 4th Industrial Revolution.

Drozdz, W., Miskiewicz, R., Pokrzywniak, J., \& Elzanowski, F. (2019). Urban Electromobility in the Context of Industry 4.0. Torun: Wydawnictwo Adam Marszalek.

Drozdz, W., Marszalek-Kawa, J., Miskiewicz, R., \& Szczepanska-Waszczyna, K. (2020). Digital Economy in the Contemporary World. Torun: Wydawnictwo Adam Marszalek.

Dzwigol, H. (2019a). The Concept of the System Approach of the Enterprise Restructuring Process. Virtual Economics, 2(4), 46-70. https://doi.org/10.34021/ve.2019.02.04(3)

Dzwigol, H. (2019b). Research Methods and Techniques in New Management Trends: Research Results. Virtual Economics, 2(1), 31-48. https://doi.org/10.34021/ve.2019.02.01(2)

Dzwigol, H. (2020a). Innovation in Marketing Research: Quantitative and Qualitative Analysis. Marketing and Management of Innovations, 1, 128-135. http://doi.org/10.21272/mmi.2020.1-10 
Dzwigol, H. (2020b). Methodological and Empirical Platform of Triangulation in Strategic Management. Academy of Strategic Management Journal, 19(4), 1-8.

Dźwigoł, H. (2020c). Interim Management as a New Approach to the Company Management. Review of Business and Economics Studies, 8(1), 20-26. https://doi.org/10.26794/2308-944X-2020-8-1-2026

Dzwigol, H., \& Wolniak, R. (2018). Controlling w procesie zarządzania chemicznym przedsiębiorstwem produkcyjnym [Controlling in the Management Process of a Chemical Industry Production Company]. Przemys/ Chemiczny, 97(7), 1114-1116. https://doi.org/10.15199/62.2018.7.15

Dzwigol, H., \& Dźwigoł-Barosz, M. (2018). Scientific Research Methodology in Management Sciences. Financial and Credit Activity: Problems of Theory and Practice, 2(25), 424-437. https://doi.org/10.18371/fcaptp.v2i25.136508

Dzwigol, H., \& Dzwigol-Barosz, M. (2020). Sustainable Development of the Company on the Basis of Expert Assessment of the Investment Strategy. Academy of Strategic Management Journal, 19(5), 1-7.

Dzwigol, H., Shcherbak, S., Semikina, M., Vinichenko, O., \& Vasiuta, V. (2019a). Formation of Strategic Change Management System at an Enterprise. Academy of Strategic Management Journal, 18(SI1), 1-8.

Dzwigol, H., Aleinikova, O., Umanska, Y., Shmygol, N., \& Pushak, Y. (2019b). An Entrepreneurship Model for Assessing the Investment Attractiveness of Regions. Journal of Entrepreneurship Education, 22(1S), 1-7.

Dzwigoł, H., Dzwigoł-Barosz, M., Zhyvko, Z., Miskiewicz, R., \& Pushak, H. (2019c). Evaluation of the Energy Security as a Component of National Security of the Country. Journal of Security and Sustainability Issues, 8(3), 307-317. http://doi.org/10.9770/jssi.2019.8.3(2)

Dzwigol, H., Dźwigoł-Barosz, M., \& Kwilinski, A. (2020a). Formation of Global Competitive Enterprise Environment Based on Industry 4.0 Concept. International Journal of Entrepreneurship, 24(1), 1-5.

Dzwigol, H., Dzwigol-Barosz, M., Miskiewicz, R., \& Kwilinski, A. (2020b). Manager Competency Assessment Model in the Conditions of Industry 4.0. Entrepreneurship and Sustainability Issues, 7(4), 2630-2644. https://doi.org/10.9770/jesi.2020.7.4(5)

Eurostat (2020). Population by Educational Attainment Level, Sex and Age. Eurostat. Retrieved from http://appsso.eurostat.ec.europa.eu/nui/submitViewTableAction.do

Ford, M. (2016). Rise of the Robots: Technology and the Threat of a Jobless Future. Moskow: Alpina non-fiction. [in Russian].

Frey, C., \& Osborne, M. (2013). The Future of Employment: How Susceptible are Jobs to Computerisation? Retrieved from http://www.oxfordmartin.ox.ac.uk/downloads/academic/future-of-employment.pdf

Furmaniak, S., Gauden, P.A., Patrykiejew, A., Miśkiewicz, R., \& Kowalczyk, P. (2018). Carbon Nanohorns as Reaction Nanochambers - a Systematic Monte Carlo Study. Scientific Reports, 15407. https://doi.org/10.1038/s41598-018-33725-z

Furmaniak, S., Gauden, P.A., Patrykiejew, A., Miskiewicz, R., \& Kowalczyk, P. (2019a). The Effects of Confinement in Pores Built of Folded Graphene Sheets on the Equilibrium of Nitrogen Monoxide Dimerisation Reaction. Journal of Physics Condensed Matter, 31(13), 135001, 1-12. https://doi.org/10.1088/1361-648X/aaffb3 
Furmaniak, S., Gauden, P.A., Patrykiejew, A., Szymański, G., Miśkiewicz, R., \& Kowalczyk, P. (2019b). In Silico Study on the Effects of Carbonyl Groups on Chemical Equilibrium of Reactions with a Polar Product Occurring under Confinement in Pores of Activated Carbons. Chemical Engineering Communications, 1-12. https://doi.org/10.1080/00986445.2019.1700115

Grossman, M. (1972). On the Concept of Health Capital and the Demand for Health. Journal of Political Economy, 2, 223-255.

Hanushek, E., Jamison, D., Jamison, E., \& Woessmann, L. (2008). Education and Economic Growth. Education Next, vol. 8, No 2.

IZA (2018). New Education Models for the Workforce of the Future. IZA Policy Paper, No 143. Retrieved from http://ftp.iza.org/pp143.pdf

Jamel, L., Ben Ltaifa, M., Elnagar, A.K., Derbali, A., \& Lamouchi, A. (2020). The Nexus between Education and Economic Growth: Analyzing Empirically a Case of Middle-Income Countries. Virtual Economics, 3(2), 43-60. https://doi.org/10.34021/ve.2020.03.02(3)

Judson, R. (1998). Economic Growth and Investment in Education: How Allocation Matters. Journal of Economic Growth, 3(4), 337-359. https://doi.org/10.2307/40215992

Kharazishvili, Y., Kwilinski, A., Grishnova, O., \& Dzwigol, H. (2020). Social Safety of Society for Developing Countries to Meet Sustainable Development Standards: Indicators, Level, Strategic Benchmarks (with Calculations Based on the Case Study of Ukraine). Sustainability, 12(21), 8953. https://doi.org/10.3390/su12218953

Kokotovic, F. (2016). A Panel Regression Analysis of Human Capital Relevance in Selected Scandinavian and SE European Countries. UTMS Journal of Economics, 7(1), 13-24.

Kondratenko, V., Okopnyk, O., Ziganto, L., \& Kwilinski, A. (2020). Innovation Development of Public Administration: Management and Legislation Features. Marketing and Management of Innovations, 1, 87-94. https://doi.org/10.21272/mmi.2020.1-06

Kuzior, A., Kwilinski, A., \& Tkachenko, V. (2019). Sustainable Development of Organizations Based on the Combinatorial Model of Artificial Intelligence. Entrepreneurship and Sustainability, 7(2), 13531376. http://doi.org/10.9770/jesi.2019.7.2(39)

Kwilinski, A. (2017). Development of Industrial Enterprise in the Conditions of Formation of Information Economics. Thai Science Review, Autumn 2017, 85-90. https://doi.org/10.5281/zenodo.1414236

Kwilinski, A. (2018a). Mechanism of Formation of Industrial Enterprise Development Strategy in the Information Economy. Virtual Economics, 1(1), 7-25. https://doi.org/10.34021/ve.2018.01.01(1)

Kwilinski, A. (2018b). Mechanism of Modernization of Industrial Sphere of Industrial Enterprise in Accordance with Requirements of the Information Economy. Marketing and Management of Innovations, 4, 116-128. http://doi.org/10.21272/mmi.2018.4-11

Kwilinski, A. (2018c). Mechanism for Assessing the Competitiveness of an Industrial Enterprise in the Information Economy. Research Papers in Economics and Finance, 3(1), 7-16. https://doi.org/10.18559/ref.2018.1.1

Kwilinski, A. (2018d). Trends of Development of the Information Economy of Ukraine in the Context of Ensuring the Communicative Component of Industrial Enterprises. Economics and Management, 1(77), 64-70. 
Kwilinski, A. (2019). Implementation of Blockchain Technology in Accounting Sphere. Academy of Accounting and Financial Studies Journal, 23(SI2), 1-6.

Kwilinski, A., Tkachenko, V., \& Kuzior, A. (2019a). Transparent Cognitive Technologies to Ensure Sustainable Society Development. Journal of Security and Sustainability Issues, 9(2), 561-570 http://doi.org/10.9770/jssi.2019.9.2(15)

Kwilinski, A., Drobyazko, S., \& Derevyanko, B. (2019b). Synergetic and Value Effects in Corporate Mergers and Acquisitions of International Companies. In Khalid S. Soliman (Ed.), Proceedings of the 34th International Business Information Management Association Conference (IBIMA) 13-14 November 2019. Vision 2025: Education Excellence and Management of Innovations through Sustainable Economic Competitive Advantage in 2019 (pp. 9467-9471). Madrid, Spain: IBIMA Publishing.

Kwilinski, A., Dalevska, N., Kravchenko, S., Hroznyi, I., Kovalenko, I. (2019c). Formation of the Entrepreneurship Model of E-Business in the Context of the Introduction of Information and Communication Technologies. Journal of Entrepreneurship Education, 22(SI1), 1528-2651-22-S1337: 1-7.

Kwilinski, A., Ruzhytskyi, I., Patlachuk, V., Patlachuk, O., \& Kaminska, B. (2019d). Environmental Taxes as a Condition of Business Responsibility in the Conditions of Sustainable Development. Journal of Legal, Ethical and Regulatory Issues, 22(SI2) 1544-0044-22-SI-2-354: 1-6.

Kwilinski, A., Volynets, R., Berdnik, I., Holovko, M., \& Berzin, P. (2019e). E-Commerce: Concept and Legal Regulation in Modern Economic Conditions. Journal of Legal, Ethical and Regulatory Issues, 22(SI2), 1544-0044-22-SI-2-357: 1-6.

Kwilinski, A., Dzwigol, H., \& Dementyev, V. (2019f). Transnational Corporations as Entities of International Entrepreneurship. International Journal of Entrepreneurship, 23(SI4), 1-6.

Kwilinski, A., Pajak, K., Halachenko, O., Vasylchak, S., Pushak, Ya., \& Kuzior, P. (2019g). Marketing Tools for Improving Enterprise Performance in the Context of Social and Economic Security of the State: Innovative Approaches to Assessment. Marketing and Management of Innovations, 4, 172-181. http://doi.org/10.21272/mmi.2019.4-14

Kwilinski, A., \& Kuzior, A. (2020). Cognitive Technologies in the Management and Formation of Directions of the Priority Development of Industrial Enterprises. Management Systems in Production Engineering, 28(2), 119-123. http://doi.org/10.1515/mspe-2019-0020

Kwilinski, A., Vyshnevskyi, O., \& Dzwigol, H. (2020a). Digitalization of the EU Economies and People at Risk of Poverty or Social Exclusion. Journal of Risk and Financial Management, 13(7), 142. https://doi.org/10.3390/jrfm13070142

Kwilinski, A., Zaloznova, Y., Trushkina, N., \& Rynkevych, N. (2020b). Organizational and Methodological Support for Ukrainian Coal Enterprises Marketing Activity Improvement. E3S Web of Conferences, 168, 00031. https://doi.org/10.1051/e3sconf/202016800031

Kwilinski, A., Dielini, M., Mazuryk, O., Filippov, V., \& Kitseliuk, V. (2020c). System Constructs for the Investment Security of a Country. Journal of Security and Sustainability Issues, 10(1), 345-358. https://doi.org/10.9770/jssi.2020.10.1(25)

Kwilinski, A., Shteingauz, D., \& Maslov, V. (2020d). Financial and Credit Instruments for Ensuring Effective Functioning of the Residential Real Estate Market. Financial and Credit Activities: 
Problems of Theory and Practice. 3(34), 133-140. Retrieved from https://fkd.ubs.edu.ua/index.php/fkd/article/view/3023

Lakhno, V., Malyukov, V., Bochulia, T., Hipters, Z., Kwilinski, A., \& Tomashevska, O. (2018). Model of Managing of the Procedure of Mutual Financial Investing in Information Technologies and Smart City Systems. International Journal of Civil Engineering and Technology, 9(8), 1802-1812.

Lau, L. J., Jamison, D. T., Lin, S.-C., \& Rivkin, S. (1993). Education and Economic Growth. Some Crosssectional Evidence from Brazil. Journal of Development Economics, 41, 45-70. https://doi.org/10.1016/0304-3878(93)90036-M

Mankiw, N., Romer, D., \& Weil, D. (1992). A Contribution to the Empirics of Economic Growth. Quarterly Journal of Economics, 107, 407-437. https://doi.org/10.2307/2118477

ManpowerGroup (2019). Humans Wanted: Robots Need You. Skills Revolution 4.0. Retrieved from https://www.manpowergroup.com/workforce-insights/world-of-work/skills-revolution-series

Miskiewicz, R. (2017a). Knowledge in the Process of Enterprise Acquisition. Progress in Economic Sciences, 4, 415-432. https://doi.org/10.14595/PES/04/029

Miskiewicz, R. (2017b). Knowledge Transfer in Merger and Acquisition Processes in the Metallurgical Industry. Warsaw: PWN.

Miskiewicz, R. (2018). The Importance of Knowledge Transfer on the Energy Market. Polityka Energetyczna, 21(2), 49-62. http://dx.doi.org/10.24425\%2F122774

Miskiewicz, R. (2019). Challenges Facing Management Practice in the Light of Industry 4.0: The Example of Poland. Virtual Economics, 2(2), 37-47. https://doi.org/10.34021/ve.2019.02.02(2)

Miskiewicz, R. (2020a). Internet of Things in Marketing: Bibliometric Analysis. Marketing and Management of Innovations, 3, 371-381. http://doi.org/10.21272/mmi.2020.3-27

Miskiewicz, R. (2020b). Efficiency of Electricity Production Technology from Post-Process Gas Heat: Ecological, Economic and Social Benefits. Energies, 13(22), 6106. https://doi.org/10.3390/en13226106

Miśkiewicz, R, \& Wolniak, R. (2020). Practical Application of the Industry 4.0 Concept in a Steel Company. Sustainability, 12(14), 5776. https://doi.org/10.3390/su12145776

McKinsey \& Company (2017). Jobs Lost, Jobs Gained: Workforce transitions in a time of automation. NY: McKinsey Global Institute.

Nelson, R., \& Phelps, E. (1966). Investment in Humans, Technological Diffusion and Economic Growth. American Economic Review, 61, 69-75. Retrieved from https://www.jstor.org/stable/1821269

Nordhaug, O. (1993). Human Capital in Organizations: Competence, Training and Learning. Oslo: Scandinavian University Press.

OECD (2017a). Education Policy Outlook: Latvia. Paris: OECD Publishing.

OECD (2017b). Education in Lithuania. OECD Reviews of National Policies for Education. Paris: OECD Publishing.

OECD (2019a). Education at a Glance 2019: Latvia. OECD indicators. Paris: OECD Publishing.

OECD (2019b). Education at a Glance 2019: Lithuania. OECD indicators. Paris: OECD Publishing. 
OECD (2020a). Educational Finance Indicators. Financial Resources Invested in Education. Education and Training. OECD. Retrieved from https://stats.oecd.org/Index.aspx?DataSetCode

OECD (2020b). Productivity. Level of GDP per Capita and Productivity. OECD. Retrieved from https://stats.oecd.org/Index.aspx?DataSetCode=PDB_LV

Osvita (2015). The Burden on University Teachers will Decrease. Higher Education Reform. Retrieved from http://osvita.ua/vnz/reform/45788/ [in Ukrainian].

Pająk, K., Kamińska, B., \& Kvilinskyi, O. (2016). Modern Trends of Financial Sector Development under the Virtual Regionalization Conditions. Financial and Credit Activity: Problems of Theory and Practice, 2(21), 204-217. https://doi.org/10.18371/fcaptp.v2i21.91052

Pająk, K., Kvilinskyi, O., Fasiecka, O., \& Miskiewicz, R. (2017). Energy Security in Regional Policy in Wielkopolska Region of Poland. Economics and Environment, 2(61), 122-138.

Pankova, O., Ishchenko, O., \& Kasperovich, O. (2020). Labour and Employment in a Digital Transformation: Priorities for Ukraine in the Context of Global Trends and Formation of Industry 4.0. Economy of Industry, 2(90), 133-160. http://doi.org/10.15407/econindustry2020.02.133 [in Ukrainian].

Pelinescu, E. (2015). The Impact of Human Capital on Economic Growth. Procedia Economics and Finance, 22, 184-190.

Prokopenko, O., \& Miśkiewicz, R. (2020). Perception of "Green Shipping" in the Contemporary Conditions. Entrepreneurship and Sustainability Issues, 8(2), 269-284. https://doi.org/10.9770/jesi.2020.8.2(16)

Radulescu, M., Fedajev, A., Sinisi, C. I., Popescu, C., \& lacob, S. E. (2018). Europe 2020 Implementation as Driver of Economic Performance and Competitiveness. Panel Analysis of CEE Countries. Sustainability, 10(3), 566. http://doi.org/10.3390/su10020566

Romer, P. (1990). Endogenous Technological Change. Journal of Political Economy, 98(5), 71-102.

Rosenzweig, M.R. (1990). Population Growth and Human Capital Investments: Theory and Evidence. Journal of Political Economy, 98(5), 38-70. https://doi.org/10.2307/2937631

Saługa, P.W., Szczepańska-Woszczyna, K., Miśkiewicz, R., \& Chłąd, M. (2020). Cost of Equity of CoalFired Power Generation Projects in Poland: Its Importance for the Management of DecisionMaking Process. Energies, 13(18), 4833.https://doi.org/10.3390/en13184833

Savchenko, T., Basiurkina, N., Rodina, O., \& Kwilinski, A. (2019). Improvement of the Assessment Methods of Product Competitiveness of the Specialized Poultry Enterprises. Management Theory and Studies for Rural Business and Infrastructure Development, 41(1), 43-61. https://doi.org/10.15544/mts.2019.05

Schultz, T. (1960). Capital Formation by Education. Journal of Political Economy, 68(6), 571-583.

Schultz, T. (1961). Investment in Human Capital. The American Economic Review, 51(1), 1-17.

State Statistics Service of Ukraine (2020). Retrieved from http://www.ukrstat.gov.ua/ [in Ukrainian].

Stiglitz, J. (2014). Unemployment and Innovation. Retrieved from https://www.nber.org/papers/w20670.pdf 
Teixeira, A., \& Queirosb, A. (2016) Economic Growth, Human Capital and Structural Change: A Dynamic Panel Data Analysis. Research Policy, 45(8), 1636-1648. http://doi.org/10.1016/j.respol.2016.04.006

The Cabinet of Ministers of Ukraine (2019). Resolution: On the Distribution of State Budget Expenditures between Higher Education Institutions on the Basis of Indicators of their Educational, Scientific and International Activities of December 24, № 1146. The Cabinet of Ministers of Ukraine. Retrieved from https://zakon.rada.gov.ua/laws/show/1146-2019-\%D0\%BF [in Ukrainian].

The Cabinet of Ministers of Ukraine (2020). Resolution: Some Issues of Introducing Indicative Cost on March 3, № 191. The Cabinet of Ministers of Ukraine. Retrieved from https://zakon.rada.gov.ua/laws/show/191-2020-\%D0\%BF [in Ukrainian].

Thurow, L. C. (1970). Investment in Human Capital. Wadsworth Series in Labor Economics and Industrial Relations. Belmont, California: Wadsworth Publishing Company.

Tkachenko, V., Kwilinski, A., Korystin, O., Svyrydiuk, N., \& Tkachenko, I. (2019a). Assessment of Information Technologies Influence on Financial Security of Economy. Journal of Security and Sustainability, 8(3), 375-385. http://doi.org/10.9770/jssi.2019.8.3(7)

Tkachenko, V., Kwilinski, A., Klymchuk, M., \& Tkachenko, I. (2019b). The Economic-Mathematical Development of Buildings Construction Model Optimization on the Basis of Digital Economy. Management Systems in Production Engineering, 27(2), 119-123. http://doi.org/10.1515/mspe2019-0020

Tkachenko, V., Kwilinski, A., Tkachenko, I., \& Puzyrova, P. (2019c). Theoretical and Methodical Approaches to the Definition of Marketing Risks Management Concept at Industrial Enterprises. Marketing and Management of Innovations, 2, 228-238. http://doi.org/10.21272/mmi.2019.2-20

Tkachenko, V., Kwilinski, A., Kaminska, B., Tkachenko, I., \& Puzyrova, P. (2019d). Development and Effectiveness of Financial Potential Management of Enterprises in Modern Conditions. Financial and Credit Activity: Problems of Theory and Practice, 3(30), 85-94. https://doi.org/10.18371/fcaptp.v3i30.179513

Tkachenko, V., Kuzior, A., \& Kwilinski, A. (2019e). Introduction of Artificial Intelligence Tools into the Training Methods of Entrepreneurship Activities. Journal of Entrepreneurship Education, 22(6), 110.

UNESCO (2016). Education for People and Planet: Creating Sustainable Futures for All. Global Education Monitoring Report. Paris, France: UNESCO Publishing.

Verkhovna Rada of Ukraine (2017). Law of Ukraine: On Education of September 5, № 2145-VIII. Verkhovna Rada of Ukraine. Retrieved from: https://zakon.rada.gov.ua/laws/show/2145-19 [in Ukrainian].

Vishnevsky, V. P., \& Knjazev, S. I. (2017). Smart Industry: Prospects and Problems. Economy of Ukraine, 7(660), 22-37 [in Russian].

Vyshnevskyi, O. (2020). Impact of Digitalization on Industry: Problems of Definition in EU Countries. Economy of Industry, 1(89), 31-44. http://doi.org/10.15407/econindustry2020.01.031 [in Ukrainian].

Vyshnevskyi, V. P. (Ed.). (2019). Smart Industry: Direct Formation, Problems and Solutions. Kyiv: Institute of Industrial Economics of NAS of Ukraine. [in Ukrainian]. 
Yelnikova, Y., \& Miskiewicz, R. (2020). Implementation Mechanism of Impact Investing in the PostConflict Regions. Financial Markets. Institutions and Risks, 4(3), 53-65. https://doi.org/10.21272/fmir.4(3).53-62.2020 